\title{
The Creativity of Bernard Shaw in the Literary-Critical Perception of K.I.Chukovsky
}

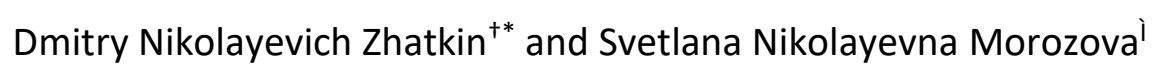

\section{Abstract}

The early reception of Bernard Shaw's creativity is of considerable interest since it helps to characterise Russian-English historical, cultural and literary connections better, being an indicator of the impact of the aesthetics and drama by B. Shaw on creating a new drama and the development of Russian theatrical art. The research aims to examine the specific perception of the creativity of the English playwright B. Shaw by K.I. Chukovsky. The focus was mostly on the article Bernard Shaw from the series of Anglo-American notebooks, which analyses the works of the English playwright, as well as his aesthetic views, are fragmented. Thus, K.I. Chukovsky paid much attention to the ideological position of B. Shaw, which social-reformist trends in a society strongly influenced formation. In particular, he noted that the adoption of socialism by B. Shaw was slightly mental than emotional, correlated with the features of the social processes that were taking place. The article contained K.I. Chukovsky's analysis of reviews of A.V. Lunacharsky on the works of B. Shaw and the statements of M. Gorky about paradoxes in English literature, fully characterising the attitude of social thought in Soviet Russia to the artistic legacy of the English playwright. It also reveals the specific understanding of the influence of creativity of $G$. Ibsen on theatrical innovations and aesthetic beliefs of $B$. Shaw, reflected in the essay Quintessence of Ibsenism. The role of the discussion as a structure-forming element in B. Shaw's dramaturgy is defined. Notes on individual plays by B. Shaw, presented in the works of K.I. Chukovsky, show that the plays of the playwright were accepted in the Russian cultural consciousness and were perceived in the light of the current social and literary trends.

Keywords: B.Shaw, K.I.Chukovsky, Russian-English historical-cultural and literary connections, literary criticism, dramaturgic techniques, paradox

\footnotetext{
${ }^{+}$Penza State Technological University, Penza, Russia

${ }^{*}$ Corresponding Author, Emails: dzhatkin@yahoo.com, ivb40@yandex.ru

'Military Academy of Logistics, Penza, Russia; Email: s.morozova09@mail.ru

(C)2019 Zhatkin and Morozova. This is an Open Access article distributed under the terms of the Creative Commons Attribution License (http://creativecommons.org/licenses/by/2.0), which permits unrestricted use, distribution, and reproduction in any medium, provided the original work is properly cited.
} 


\section{Introduction}

Bernard Shaw was perceived differently in the world literary criticism, depending on the views prevailing at different times (Holroyd, 2015; Clare, 2016; Martín, 2017). He turned out to be an artist-sociologist and satirist, then an analyst, in whose work a significant complication of the realistic artistic direction was observed (Zhatkin, 2015; Watt, 2018).

Literary-critical works of K.I.Chukovsky made a significant contribution to the popularisation of the creativity of the English author in Russia; the value of them consists in examining the aesthetics and drama of B.Shaw through the prism of the main philosophical and artistic trends of contemporary Russian culture. The popularity of B. Shaw's creativity in Russia was determined, in the opinion of K.I.Chukovsky, by the fact that the English playwright proved to be a rebel, agitator and stagger of the foundations: Each of his plays is a riot. In each, he denounces some sin of our time (Chukovsky, 2012:320).

The topical character of the plays, according to K.I.Chukovsky was associated with the moral, political and economic issues, B.Shaw proposed for discussion. The plays of the English playwright were close to the realistic dramas of G.Ibsen, in which the public, together with the main characters, was called upon to solve the posed social problems.

The creativity of B.Shaw, being voluminous and representative, facilitated the emergence of a large number of studies, devoted to his artistic heritage, cultural and historical context of creativity, a vector of genre searches (Kent, 2015; Krivonogova, 2001). Along with the above works, which made a valuable contribution to the literary interpretation of B. Shaw's work, the literary-critical articles of K.I. Chukovsky played a significant role in the perception of his heritage in Russia, having synthesised various forms of reception of the playwright's works, thus having contributed to their promotion and popularisation.

In this research, the specific perception of the creativity of B. Shaw by K.I. Chukovsky is presented. The research is a discussion on the content of the Bernard Shaw by Chukovsky from Anglo-American notebooks series.

The article consists of six main sections. In the introduction section, we have outlined that the early reception of Bernard Shaw's creativity is really of interest. The analysis of Shaw's creativity is presented from Russian literary critic. Thus, main results are divided into four thematic subsections: The Path towards the World of Creativity by Bernard Shaw in Russian Community; Chukovsky on Bernard Shaw's Ideology; In The Chase for New Genres and Forms of Expression; and The Life and Creativity of Bernard Shaw as K.I. Chukovsky Saw It: Viewport Jumping Experience.

\section{Results}

\section{The Path towards the World of Creativity by Bernard Shaw in the Russian Community}

Russian readers became acquainted with the works of Bernard Shaw at the turn of the XIX-XX Centuries. The first complete collection of works by the English playwright in ten volumes was published in 1910-1911. In this edition, there was published a positive response of L.N. Tolstoy, which in many ways determined the attitude of the Russian public to the works of Shaw.

K.I. Chukovsky became intimately acquainted with the works of B. Shaw in 1908 when editing the play The Devil's Disciple, translated by I. Danilov, published in a separate edition. From this moment, the creativity of B. Shaw became part of the literary interests of the Russian writer. In 1921, in the first issue of the edited by K.I. Chukovsky magazine Contemporary West there was published a review of B. Shaw's play Back to Methuselah (1922), which gave the analysis of the drama and specific aspects of its perception by the Russian readers. K.I. Chukovsky examined the substantive problems, characterising certain aesthetic representations of B. Shaw.

The article on K.I. Chukovsky Bernard Shaw from the series of Anglo-American notebooks was 
dedicated to the English playwright. It was first published in 1922 as a preface to a collection of plays by B. Shaw in translations of Z.A. Vengerova, V.D. Perazich and L.A. Sulerzhitsky. The article gave an analysis of several works by B. Shaw, some facts of his biography. K.I. Chukovsky, in particular, wrote that the writer's biography is poor of external events, having noted the mediocrity of his childhood and adolescence: His mother Lucinda Elizabeth Gurly, a well-known opera singer, was a singing teacher in London in her old age. The family had to be tight. Fifteen years of age, Bernard Shaw was compelled to earn his living by work. Five years he served as a clerk at a land agency in Ireland, and then moved to London and entered the office of a Telephone Company. There he wrote three novels that were not a success (Chukovsky, 2012:110).

\section{Chukovsky on Bernard Shaw's Ideology}

K.I.Chukovsky paid great attention to the analysis of the ideological positions of B. Shaw, whose worldview was formed under the enormous influence of the famous poet and reformer William Morris (Chukovsky, 2012). This influence determined the social orientation of the playwright since $W$. Morris was a propagandist and follower of socialism and was the founder of the Socialist League (1885). B. Shaw was also a socialist by his convictions: Back in 1884 he joined the so-called Fabian Society and began to preach socialism in the streets, parks, rallies, articles and brochures (Chukovsky, 2012:64). The activities of the Social-Reform organisation consisted of coordinating the labour movement with an emphasis on the need for waiting and avoiding decisive action. A similar strategy was inherent in many heroes of B. Shaw's works, who were adherent to the theoretical postulates of an organised society. The softening of the class struggle and the involvement of the bourgeoisie and the Parliament became the basis of the ideological trend of the social reformist organisation. The transition from capitalism to socialism, according to the organisation supporters, should be carried out through reforms.
B. Shaw was active in the organisation, cofounder of which he was. As one of the leaders of the society, B. Shaw was engaged in the propaganda of socialist ideas, publishing agitation tracts and books. K.I. Chukovsky enumerated some of them and wrote about the attitude to them in society: His articles The Economic Basis of Socialism, The Transition to Social Democracy and Socialism for Millionaires were a massive success at the time (Chukovsky, 2012). The writer also noted that B. Shaw's socialism was not emotional, but intellectual, generated by the middle classes of English society. K.I. Chukovsky also analysed the main programmatic issues of the socialists in relation to the work of B. Shaw. The Fabians considered it possible to carry out reforms with the help of peaceful propaganda and logical influence, urging the bourgeoisie to recognise the irrationality of the bourgeois system. In the works of the English writer, as K.I. Chukovsky noted: this purely British utilitarian logic is combined ... with the lively playfulness of the Irish mind, which enables the writer to clothe the most serious and complex moral and social topics in eccentric, funny and amusing forms (Chukovsky, 2012:97). K.I. Chukovsky explained the addiction of the playwright to the comedy and farce by his Irish descent.

B. Shaw's ideological views were not always positively perceived by Russian publicists and philosophers who wanted to see him as a representative of critical realism. In the article, Lunacharsky, K.I.Chukovsky noted the opposition of the Soviet public figure, publicist and critic of some of B. Shaw's views: Lunacharsky refers to the English playwright with great respect, though he does not favour his Fabian illusions (Chukovsky, 2012:103). Being the founder of the methods of study of B. Shaw's creativity in Russia, A.V. Lunacharsky considered the playwright not only an ideological author but also a robust social satirist. A.B. Lunacharsky's description of B. Shaw's creativity was valuable, in the opinion of K.I. Chukovsky, due to his impartiality: ...Lunacharsky got ... strict and exacting even to his favourite authors, when finding even the slightest hint of "humanity" in their works; one can imagine the way he did hate 
those "humanities" and rebel against them, having found a pure and unmixed form of them in writers, who looked like "the sheep type, in fact, being the wolf type (Chukovsky, 2012:105). Accepting the work of B. Shaw, A.V. Lunacharsky demonstrated its consonance with the current era, demanding with unremitting energy to eradicate hostile tendencies in literature, theatre, and music (Chukovsky, 2012:112).

A.V. Lunacharsky $(1957: 276)$ was one of the first to show the synthetic nature of the comic in drama of B. Shaw, whose wit was purposely hyperbolised to surprise the audience, and too serious to only bear ironic overtones: The wit of B. Shaw is at the same time too broad, unorganised, masterly and exaggerated so as not to shock the refined taste or routine of the big public, and too intellectual, logical, so as to pass for the vulgar witticism of modern merrymakers. A.V. Lunacharsky concluded that B. Shaw's buffoonery was profoundly philosophical and that ideas in their paradoxical coverage were extremely serious.

K.I. Chukovsky sees some ambiguity in the criticism of A.V. Lunacharsky, because, after having defined B. Shaw as "the wittiest writer in Europe", "a paladin of vigorous and smashing laughter", and having equated him to Voltaire and to Heine, after using these semi-ironic, halfenthusiastic words, he started arguing that Bernard Shaw was mixing "dirty water" with his pure thoughts and noble impulses; that, if you had removed the Voltaire mask from him, you would have easily found underneath a "respectably combed" head of a by no means quite brave petty-bourgeois intellectual (Chukovsky, 2012:125). Nevertheless, A.V. Lunacharsky considered the social and philosophical orientation of his plays being undoubted merit of the playwright.

The Soviet critic also expressed his preference for the plays of B. Shaw. K.I. Chukovsky notes his response to one of them: Everywhere in his books, from under the soft wax, there appears a flintstone. So is, for example, both the laudatory and malicious article about the "Black Girl" by Bernard Shaw (Chukovsky, 2012:166). Stressing the aversion of A.V. Lunacharsky of the excessive number of paradoxes in B. Shaw's plays that harmed the artistic performance and led to the effect, opposite to the author wanted to receive, K.I. Chukovsky noted that the surprise in such plays was often replaced by boredom.

M. Gorky reflected on paradoxes in English literature in a letter to K.I. Chukovsky in connection with the publication of the collected works of $\mathrm{O}$. Wilde, to which the writer gave an introductory essay in The World Literature. M. Gorky spoke about the phenomenon of O. Wilde and B. Shaw and noted that, although the works of these writers were a surprise for England at the end of the 19th century (Bahnova, 2017), their style of working and the themes raised were logical, since the paradox in the field of morals was a very legitimate weapon in the struggle against Puritanism: I also believe that Wilde is not alien to the influence of Nietzsche (Chukovsky, 2012:200). The first works of B. Shaw, published in The World Literature, were the following plays: anti-romantic comedy Arms and the Man (1894), Captain Brassbound Conversion (1899) and Caesar and Cleopatra (1898). The first play was included in the collection Plays Pleasant (1898) by the playwright, the other two entered the cycle Three Plays for Puritans (1901). In Plays Pleasant B. Shaw focused on the problems of morality, carried out with great philosophical depth.

In his article, K.I.Chukovsky noted another group of plays by B.Shaw - a cycle of early works under the title Plays Unpleasant, including texts that highlighted the social problems that showed the gloomy aspects of the social order. Because of the revolutionary nature of the image of reality, many plays by Shaw were banned by the British theatre censorship and only later they saw a ramp (Chukovsky, 2012). According to K.I.Chukovsky, the playwright «likes to stand one against all and tease public opinion», being primarily a fighter even in the presentation of his aesthetic views (Chukovsky, 2012:179). B. Shaw showed that even the external respectable appearance of the bourgeoisie, possessing considerable capital and leading a calm and measured life, could not hide the facts of exploitation and dishonest enrichment at the 
expense of labour and the plight of ordinary people.

It was his passion for the creativity of G.Ibsen, the greatest playwright of the late XIX century, that allowed B.Shaw to expose the ideals of modern society and its deceit. Following his theatrical traditions, B.Shaw spoke out against well-made plays, accessible on the stages of Western European theatres. His reflections over the tasks of modern drama were outlined in the work- The Quintessence of Ibsenism (1891), which became a manifesto of his work. K.I.Chukovsky draft the main line of this work: In the years, when the British considered Ibsen a worthless scribe, Shaw made - one against all a polemical book, where he placed lbsen next to Shakespeare (The Quintessence of Ibsenism, 1891) (Chukovsky, 2012). B. Shaw raised the drama of Ibsen, while making attacks against Shakespeare, although the criticism was not directed at the real works of Shakespeare, but on the interpretation of his plays in the theatre. K.I.Chukovsky explained these polemics by the unique aesthetic position, taken by the English playwright, in which plays, like in the plays of the representatives of the new drama, the current philosophical problems were put on a prominent place. Therefore, in the plays of B.Shaw, the elements of the new drama, like the internal conflict, the plot of sentiments, the principle of double dialogue, subtext, open finals, prevailed.

Like G.Ibsen, B.Shaw referred to a new artistic form - a form of discussion in the paradoxical drama of ideas. Discussions led by B.Shaw's heroes were designed instead show the problem under discussion in its paradoxical and illogical development, focusing on it, than to find a solution to it, while the nature of the issues discussed was often reflecting the author's civil position. In K.I.Chukovsky's words, aesthetics is not enough for him [Shaw]>. He pays most attention to public issues. Here he's got a lot of space for rebellious inclinations (Chukovsky, 2012:138).It is indeed arguable that these discussions have created figurative system reflecting the positions of various social groups, as well as the dominant psychological moods of the era.

\section{In the Chase for New Genres and Forms of Expression}

B. Shaw paid much attention to Russian culture, which played an essential role in the development of his aesthetic views. So, K.I.Chukovsky denoted the importance of the work of A.P. Chekhov for B.Shaw's art world: Similarly, arguing and cursing, he won, about ten years ago, an honorable place for "Uncle Vanya" of our Chekhov (Chukovsky, 2012:134). The works of the Russian writer brought significant changes in the playwright's art system. The Chekhov dramas, which had severe social and philosophical problems at their heart, were not popular on the stage of the English theatre and could not compete with emotional dramas. In the atmosphere of ill will, developed around B.Shaw, A.P.Chekhov became the mainstay in his struggle against reactionaries in literature and politics. A discussion of the English playwright and A.P.Chekhov made many works of B.Shaw acquire fictional character. It is therefore arguable that there has been a great influence of the works of the Russian; indeed the classical ones can define the genre of many of his dramas as epic.

Among his experimental plays K.I.Chukovsky singled out the philosophical pentology Back to Methuselah, in which a paradise was depicted, where Adam and Eve were sitting under the tree of knowledge of good and evil, and, without departing from the scene, argued throughout the first act about different issues (Chukovsky, 2012:127). This drama was received enthusiastically by the audience. According to K.I.Chukovsky, no other Shaw's play had ever provoked so much controversy, applause, articles, condemnations, praises - and what was more important, so much laughter - than this one, magnificently produced by the "Theatre Workshop" in New York (Chukovsky, 1922:138). Laughter was due to the fact that B. Shaw used the tradition of Swift satire in his pentology. The form of paradox and farce was used to attract the viewer's attention to the development of various spheres of life in different time epochs, rather than to comprehend images of heroes in a comic form. The idea, being original, made this 
very play, according to K.I. Chukovsky, to be the hugest worldwide success (Chukovsky, 1922:34).

The innovative organisation of the story could also explain the popularity of the play. Instead of a traditional plot, based on external action, B.Shaw presented a new one, based on the movement of ideas, psychic life and the development of the thoughts of the characters in the play. Therefore, the five parts of the drama gave the impression of scattered, unrelated fragments. In K.I.Chukovsky's words, in fact, this was not one play, but five, played in three consecutive nights, and the action of the last occurred forty thousand years after the first (Chukovsky, 1922:57). The plot of pentalogy was united by the evolutionary theories of B.Shaw, earlier having only been outlined in his works.

In the play Arms and the Man (1894) the girl, who hosted the enemy, argued with him all night long (Chukovsky, 2012:132), their discussion bearing the idea of destroying the romantic image of war, of denying the possibility of the poetising of human cruelty. As a result of the analysis, K.I.Chukovsky concludes that all the main characters of Shaw are desperate debaters, loving the dialectics most of all, while in every play there is one person who reveals to others what the genuine truth of life is (Chukovsky, 2012:176).

The substantive aspect of B. Shaw's creativity was conditioned by the desire to reform many theatrical trends, in particular, the analytical theatre and the theatre of the absurd (Deutch, 1966; Balashov, 1982; Watt, 2018). Paradoxes, which the playwright used to show the social vices of society in a hyperbolised form, had a significant role in revealing the social meaning of the phenomena in his plays: Bernard Shaw likes to make his plays absurd, without neglecting clowning. Chukovsky found this technique in the play Back to Methuselah, where huge eggs are put on the stage, from which, in front of spectators, five-year-old children hatch (Chukovsky, 2012:213); in the same play, he brings to the stage two contemporaries - the English ministers Lloyd George and Asquith. The paradoxes of B. Shaw were directed against the hypocrisy of bourgeois morality, helping to understand the contradiction between the appearance and the essence of the phenomenon, to reveal the shortcomings of society and the absurdity of traditional ideas.

K.I.Chukovsky called the play Caesar and Cleopatra by B. Shaw pure Offenbach-like, having marked only one specific feature in it behind all the most reckless jokes ... there is a strict puritan idea about the need to save a sinful world (Chukovsky, 2012:101). Paradoxes of B. Shaw are not only a witty play of words but objective judgments of the playwright about the surrounding, which help people to see things in their true light. The exposure of the hypocritical world is represented in B.Shaw's play, Mrs. Warren's Profession (1894), which was successful in theatres. The paradox is that the venerable aristocrat turns out to be the owner of brothels (Chukovsky, 2012:89). According to K.I.Chukovsky, the topical plot of this led to the fact that the play was staged in America only in 1905, and all the troupe was prosecuted for staging an immoral play (Chukovsky, 2012:102).

In the play Candida (1894-1895), written at the same time, B.Shaw used a new dramatic technique - the final discussion. The author himself determined the genre of the work as modern pre-Raphaelite drama. The conflict in the play was resolved through a detailed explanation between the characters. Chukovsky explained the popularity of Candida by the fact that in England, questions about love and marriage are still forbidden (Chukovsky, 2012:278). Social, political and aesthetic issues, discussed by the main actors of the play, transformed the domestic, limited by the narrow Morrel's family circle problem into a socialphilosophical one. An open final helped to show that the personal liberation of the hero, who found his right path, did not mean the end of the conflict. With the end of the play, the real test of the hero's strength and his self-affirmation in life began.

Not always did KI. Chukovsky gave high marks to the heritage of B. Shaw. In the post-war years in his diary dated 30 December 1956, KI. Chukovsky gave a critical evaluation of the play Widower's Houses (1885) by B.Shaw, which he 
called cold brain products without a shadow of inspiration - and life (Chukovsky, 2012:156). At the same time, K.I.Chukovsky was aware that it was B. Shaw who proposed the qualitatively new ways of creating a dramatic text. These innovations caused specific difficulties when staging plays in the theatre, which was pointed out by K.I.Chukovsky in his diary dated 9 December 1923, who quoted the words of the actor of the Bolshoi Dramatic Theater N.F.Monakhov: Then they gave us N.V.Solovyov ... Well, he's just a straggler! He undertakes staging of Bernard Shaw's "Mile Brastound's Convention" - staging, staging, but does not know how to say a word. Not able to. So they asked A.N.Lavrentiev to take this case under his own responsibility (Chukovsky, 2013:104). So, the majority of Shaw's plays, being difficult in the ways of reporting dramatic action, since they were full of artistic and philosophical generalisations, were not staged. Rephrase this sentence for clarity Another reason for neglecting the plays of B. Shaw, K.I.Chukovsky saw in the specifics of the issues, raised by him, for example, There is no English opera ... at all. There is an operetta - but not provocative, teasing, joyful, but some virtuous, skinny, tightly buttoned (Chukovsky, 2013:214). The tasks of drama were reduced to covering the everyday events, which were not affecting the realities of modern life, and social processes. According to K.I.Chukovsky, [Shaw] does not have any foreign influence, and therefore his plays, capable of having great success, here fall out of the ordinary (Chukovsky, 2013:144).

\section{The Life and Creativity of Bernard Shaw as K.I.Chukovsky Saw It: Viewport Jumping Experience}

In some cases, the interpretation of biography and creativity of B.Shaw, performed by K.I.Chukovsky differed from the traditional ideas, which, in particular, concerned understanding of the peculiar worldview of the English playwright. In modern Russian literary criticism, accents and guidelines for studying the aesthetic and ideological views of B. Shaw have changed significantly. If K.I.Chukovsky perceived the playwright as an artist-sociologist and a satirist; then, many researchers later began to see him as an analyst in whose creativity the realistic direction was significantly complicated and updated. Another interpretation implied studying the aesthetics and drama of B. Shaw in the context of the main philosophical and artistic points of Nietzscheanism.

Interpretation of K.I.Chukovsky is based on the fascination of B. Shaw with the ideas of socialism. In his works, B.Shaw, according to his reforming Fabian illusions, developed the idea of the incorrigible depravity of the world and man. The playwright was looking at this sad state of humankind as the result of the world war. In the play Heartbreak House, his thoughts about the spiritual decay of contemporary society were reflected. K.I.Chukovsky (2013:303) noted the success of this play in England, accentuating its explicit anti-militaristic orientation: This year, 1922, in London, there is the play ... "Heartbreak House", staged with great success, which depicts the decay of society on the eve of the war. In the genre of this play, which the playwright defined as a fantasy in the Russian style on English themes, there was a connection with the tradition of the Chekhov Theatre. The Russian writer helped B. Shaw to reveal the topic, which was seen and outlined in his early works, - the idea of the internal crisis of the bourgeois world, the exhaustion of its spiritual and practical life. The English playwright singled out in the works of A.P. Chekhov the ideas that most corresponded to his ideological views. While in A.P.Chekhov's dramas, not the characters themselves were guilty, but the time they lived in, B. Shaw blamed the intellectuals, not engaged in productive work, having said that, being far from the real life, British intellectuals prepared a military catastrophe by its inaction. B. Shaw laid out his position on this issue in a lengthy preface - an extensive pamphlet, where the author proves all the madness of the war against the Germans (Chukovsky, 2012:194). K.I.Chukovsky noted the thrust of this message, which predetermined the inevitable destruction of the centuries-old development of bourgeois civilisation. At a personal level, the play turned out to be the original outcome of the dramatist's many years of activity, aimed at improving the 
dominant social system. B. Shaw's dreams of creating a new world order in the conditions of a deep decay of the existing way of life turned out to be a naive utopia.

Despite the existing internal discord, B.Shaw continued to uphold the writer's right to speak the truth through his works. Every playwright, in his opinion, should primarily pay attention to the depth of the problems of his works and the strength of his public echo. K.I.Chukovsky noted that in his works, B.Shaw was always keeping this principle: it seems that there is no evil in modern social life, against which he would not rise. He denounced the war, and family life, the medical corporation, and the church. Almost every one of his plays is prefaced with a series of accusations against this or that sin (Chukovsky, 2012:100). For B.Shaw, the main duty and responsibility of the writer is to respond to the modernity. The English playwright tried to tell people the truth about the society they live in.

With that, there were some contradictions in B. Shaw's controversy with the principles of most of his contemporary plays, sought for escaping the discussion of the most important social problems of the time: Like any social reformer, he is, by his very nature, an optimist. You only need to correct these and those flaws of our local world in order to have the world transformed, and became the best of the worlds (Chukovsky, 2012:46). B. Shaw, defending his Fabian ideas about the structure of society, believed that social defects were the result of the moral degradation of society, which had no desire to understand its shortcomings. The change of the social environment must be carried out by evolution, based on the personal will of each person. In his work, according to K.I.Chukovsky, B.Shaw tried to solve these tasks in a very unusual way: In general, the world is good, but it needs some repairing. It is for the sake of this repairing, for making us to do this repairing, does Bernard Shaw write his plays (Chukovsky, 2012:503). B. Shaw reduced the change of society to logical maxims, making his plays somewhat speculative and moralising. In such works, the discussion prevailed over the action. According to K.I.Chukovsky, the proofs of the
English playwright were witty and persuasive, and if only the logic was enough to eradicate evil, the whole of England would long ago have been reborn by Bernard Shaw's plays: there would be no sins or vices left in England (Chukovsky, 2012:382).

The discussion on the nature of the works of $B$. Shaw allowed him, through analysis and synthesis of opinions, to come to an agreement, and to solve the posed problem, to mutual understanding. K.I.Chukovsky gave his understanding of the evidence in the works of B.Shaw: In the preface - as well as in the play Shaw tries to logically prove that evil is not only evil but also stupidity, that it will be wiser and more profitable to immediately eliminate this evil. He acts on the readers' minds rather than on their feelings; he does not curse, but proves. He proves that it would have been wiser and more profitable for all mankind not to put criminals in prisons that it would have been wiser and more profitable to give freedom to women and that it would have been wiser and more profitable to abandon war once and forever, etc. (Chukovsky, 2012:401). The main characters of B.Shaw were arguing on different subjects, and the contradictions that arose were not hushed up but were being pushed, allowing the author to draw the viewer's attention to the issue under discussion. The reader, guided by his views, could choose the most acceptable point of view and see the same subject of discussion from the point of view of different persons.

K.I.Chukovsky saw both positive and negative moments in this method of depicting reality. The skill of B.Shaw as a writer was expressed in his dialogues, where he is brilliant, witty, resourceful, full of aphorisms, paradoxes, caustic and well-aimed words (Chukovsky, 2012:487). His weakness consisted of relying on logic, which, no matter how brilliant, could not influence the human heart, being at the mercy of emotions. Moreover, even in the Plays Unpleasant, exposing the vices of society, according to K.I.Chukovsky, are very pleasant plays, pleasant even for those, who he [Shaw] so cleverly denounces: The denounced ones with pleasure admire them, admire the accusatory 
speech in which this prosecutor is exposing them with such brilliant talent, and they applaud him in the most successful places (Chukovsky, 2012:176). K.I.Chukovsky believed that, in spite of the rebellious spirit of many works by an English playwright who only spoke of trouble to the middle class of English society, intellectual action still prevailed over the real and all the accusations and reproaches of the bourgeoisie were safe and even enjoyable: No one so much loves a safe riot, as the middle classes of English society (Chukovsky, 2012:522).

That is why B. Shaw's positive hero is a person who really sees life, guided in his actions not by romantic illusions, but by the demands of reason. Already at an early stage in the work of B.Shaw, there was an opposition between the realist and the romantic, the businessman and the person who prefers abstract conversations to real action. These two types of character are found in many plays by B.Shaw.

\section{Conclusion}

The analysis of the critical literary reception of B.Shaw's works, done by K.I.Chukovsky helps us both to reconstruct the history of the perception of the English playwright in Russia and to understand the specifics of the Russian cultural relations.

Contemporaries of K.I.Chukovsky perceived B.Shaw as a social artist with a heightened sense of justice. K.I.Chukovsky was one of the first in Russia to characterise B. Shaw's artistic relations with Russian writers. In his literary critical works, the features of B.Shaw's dramatic method were most clearly defined, namely, the plot-forming discussion, lengthy prefaces, and the absence of the dividing the plays into actions and acts. As a whole, the K.I.Chukovsky's perception of creativity of B.Shaw helps to understand the most significant effect that the artistic legacy of the English playwright has on the worldview of the Russian intelligentsia.

\section{References}

Bahnova, Y. A. (2017). O. Wilde's" The Harlot's House" Translated by Fyodor Sologub: Style and Concept Features of The Translated Text. Tomsk State University Journal, 423, 15-19.
Chukovsky, K.I. (2012). Collected Works, In 15 vols. Contemporaries; Application Comp., comment. By E. Chukovskaya (vol. 5, pp. 480). Moscow, TERRA-Book Club.

Chukovsky, K.I. (1922). Back to Methuselah: [Play by B.Show]. Contemporary West, 1, 170.

Chukovsky, K.I. (2012). Collected Works: In 15 vol. High Art; From the Anglo-American notebooks, Comp. by E. Chukovskaya and P. Kryuchkov (vol. 3, pp. 640). Moscow. TERRABook Club.

Chukovsky, K.I. (2013). Collected works, In 15 vol. Diary of 1901-1921. Foreword. V. Kaverin; Comments. E. Chukovskaya (vol. 11, pp. 592). Moscow, TERRA-Book Club.

Chukovsky, K.I. (2013). Collected works, In 15 vols. The Diary (1936-1969). Comments by E. Chukovskaya (vol. 13, pp. 640). Moscow, TERRABook Club.

Chukovsky, K.I. (2013). Collected works, In 15 vols. The Diary (1922-1935). Comments by E. Chukovskaya (vol. 12, pp. 656). Moscow, TERRABook Club.

Clare, D. (2016). Shaw and the Stage Englishman in Irish Literature. In Bernard Shaw's Irish Outlook (pp. 67-121). Palgrave Macmillan, New York.

Holroyd, M. (2015). Bernard Shaw: The New Biography. Head of Zeus.

Kent, B. (2015). George Bernard Shaw in Context. Cambridge University Press.

Krivonogova, S.A. (2001). Left Fabianism: social ideas and views into the future (pp. 97).. Magnitogorsk, MSU.

Lunacharsky, A.V. (1957). Articles about literature (pp. 732).. Moscow, State Literature Publishing House.

Martín, G. A. R. (2017). Introduction: Shaw and Classical Literature-What You See Is Not Always What You Get. Shaw, 37(1), 1-10.

Watt, S. (2018). Introduction: On Money, Psychology, and Affect in Bernard Shaw's Writing. In Bernard Shaw's Fiction, Material 
Psychology, and Affect (pp. 1-41). Palgrave Acknowledgements

Macmillan, Cham.

This research is a part of the project \#17-18-

Watt, S. (2018). Bernard Shaw's Fiction, Material 01006 - The Evolution of the Russian Poetic

Psychology, and Affect: Shaw, Freud, Simmel. Translation (the XIXth-the beginning of the XXth Springer. centuries) of the Russian Science Foundation.

Zhatkin, D.N., Futlyaev, N.S., Aksenov, I.A., \& Meyerhold, V.E. (2015). An unpublished translation of the play «Heartbreak House» by B.Shaw and its stage edition (based on RGALI materials) (pp. 330-427). Art translation and comparative literary criticism. III: Collection of scientific papers. Managing Editor D.N. Zhatkin. Moscow, Flint; Science.

\section{About the Authors}

Dmitry N. Zhatkin, a Doctor of Philological Sciences, is a Professor, Head of the Department Translation and Translation Study, Penza State Technological University, Russia.

Svetlana N. Morozova is a candidate of Philological Sciences and an Associate Professor of the Russian Language, Chair at Military Academy of Logistics, Russia. 